\title{
超臨界二酸化炭素による環境適合型反応プロセス を伴う高イオン伝導性ポリマーの開発
}

東京工業大学大学院理工学研究科 富 永 洋 -

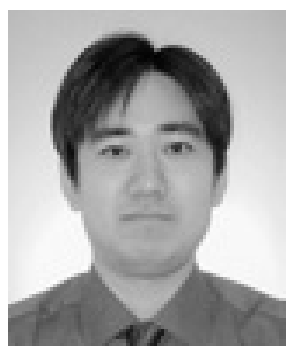

\section{1.緒 言}

イオン伝導性ポリマーは、無機系材料では実現できない 材料物性を多数有しているため、プラスチック電池や表示 素子などへの応用や、将来的には新しいイオニクス分野の 開拓も期待されている。ところが、固体状態を維持したま ま室温で $10^{-4} \mathrm{~S} / \mathrm{cm}$ を超えるイオン伝導度を発現すること は難しく、新たな改善策が求められている。一方、超臨界 二酸化炭素 $\left(\mathrm{ScCO}_{2}\right)$ は、古くから抽出・分離溶媒として利 用されており、また近年では高分子合成や発泡・微粒子. 結晶化など高分子加工用媒体としての利用にも注目が集 まっている。このような研究背景をもとに、筆者らは $\mathrm{scCO}_{2}$ 中で多くの高分子材料のガラス転移温度 $\left(T_{\mathrm{g}}\right)$ が低下する現 象(可塑化)に着目し、光の効果を利用したイオン伝導性ポ リマーの特性改善について初めて検討した。本研究では、 結晶性ポリエチレンオキシド(PEO)と各種リチウム塩か ら成る複合体フィルムの $\mathrm{ScCO}_{2}$ 処理中及び処理後のイオ ン伝導度の変化について検討した。

\section{2. 実 験}

試料は、PEO ( Mw : 500,000)及び $\mathrm{LiCF}_{3} \mathrm{SO}_{3}(\mathrm{LiTf})$ から作 製した $\left(\mathrm{PEO}_{x}-\mathrm{LiTf}, \mathrm{x}=[\mathrm{OE}] /\left[\mathrm{Li}^{+}\right]=40 \sim 3(2.5 \sim 33.3 \mathrm{~mol} \%)\right)$ 。 各フィルムは、 $100^{\circ} \mathrm{C}$ に保温した SUS-Ni 合金製の高圧反 応容器中に導入し、 $\mathrm{CO}_{2}$ ガスを送液ポンプで反応容器中に $10 \mathrm{ml} / \mathrm{min}$ の流速で送り込んだ後、圧力を $20 \mathrm{MPa}$ で 30 分 間保持した。 $\mathrm{ScCO}_{2}$ 処理後は、反応容器を直ちに冷水中に 投入し、残留 $\mathrm{CO}_{2}$ ガスを素早く放出した。取り出したフィ ルムは、直ちに室温で 24 時間真空乾燥を施し、 $\mathrm{ScCO}_{2}$ 処 理フィルムとした。 $\mathrm{scCO}_{2}$ 処理中のイオン伝導挙動は、才 リジナル反応容器中に測定セルを固定して一定圧力・温度 下で測定した。

\section{3. 結果及び考察}

$\mathrm{ScCO}_{2}$ 末処理及び処理後の PEO-LiTf 複合フィルム $(\mathrm{x}=10$, 7)のイオン伝導度の温度依存性を図 1 に示す ${ }^{1)}$ 。処理後 フィルムのイオン伝導度は広い温度範囲で改善された。特 に、 Li 塩濃度の高い試料(P7) は $\mathrm{SCCO}_{2}$ 処理の効果が大き く、またPEO 結晶相の融解に基づく相転移の低温域シフ 卜も見られた。 $\mathrm{CO}_{2}$ 分子のフィルム内浸透に伴う可塑化効 果によるものと考えられる。光こで、 $\mathrm{ScCO}_{2}$ 処理中のイオ ン伝導挙動を測定したところ、 $\mathrm{CO}_{2}$ 圧の増加に伴うイオン 伝導度の著しい増加が認められた (図 2) $)^{2)}$ 。このような傾 向は加圧 $\mathrm{N}_{2}$ 下では見られず、基本的にイオン伝導度は負 の圧力依存性を示す。ところが、加圧 $\mathrm{CO}_{2}$ 下では正の圧

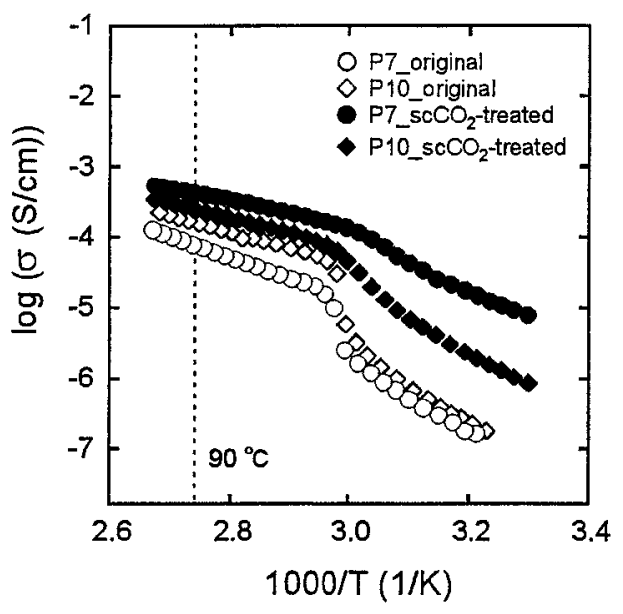

Fig. 1 Temperature dependence of ionic conductivity for original and $\mathrm{scCO}_{2}$ treated samples of $\mathrm{P} 10(x=10)$ and $\mathrm{P} 7(\mathrm{x}=7)$.

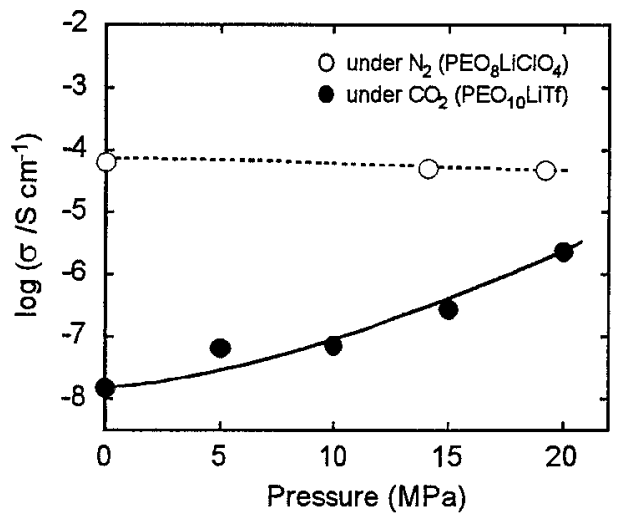

Fig. 2 Pressure dependence of ionic conductivity at $40^{\circ} \mathrm{C}$ under $\mathrm{CO}_{2}$ and $\mathrm{N}_{2}$ quoted from J.J. Fontanella et al., Solid State Ionics, 9-10, 1139(1983).

力依存性であり、これは $\mathrm{CO}_{2}$ に特有の現象であると言え る。つまり、超臨界状態において試料中へ浸透した $\mathrm{CO}_{2}$ 分子が、高分子鎖やイオンとの間に Lewis 酸-塩基相互作 用を形成し、Tgの低下やイオン解離が促進されたために 引き起こされたものと推察される。他の試料の結果は、現 在投稿準備中である。

1) Y. Tominaga, Y. Izumi, G. H. Kwak, S. A sai, M. Sumita, Macromolecules, 36, 8766(2003).

2) Y. Tominaga, G. H. Kwak, S. Hirahara, S. Asai, M. Sumita, Polymer, 44, 4769(2003).

3) Y. Tominaga, S. Hirahara, S. Asai, M. Sumita, in preparation. 